\title{
Open study of short course Fleroxacin for Typhoid and Paratyphoid Fever
}

\author{
R.H.H. Nelwan
}

\begin{abstract}
Abstrak
Tujuan utama dari penelitian ini adalah untuk mengevaluasi efikasi klinik dan bakteriologik fleroxacin jangka pendek pada penderita demam tifoid dan paratifoid tanpa komplikasi. Penderita dengan demam dan minimal dua gejala khas demam tifoid lainnya yang belum menerima pengobatan anti tifoid sebelumnya, dan memenuhi semua persyaratan eksklusi dan inklusi direkrut untuk penelitian ini. Tiga puluh penderita yang telah dibuktikan mengalami demam tifoid dan demam paratifoid berdasarkan hasil pemeriksaan bakteriologik dan serologik telah dianalisa. Mereka terdiri atas 15 pria dan 15 wanita berumur antara 18 - 38 tahun, rata-rata 27,5 tahun dengan isolasi S.typhi (16) dan S.paratyphi A (2) dari darah. Dua belas kasus lainnya diagnosa berdasarkan agglunisasi serologi Widal yang bermakna. Kasus-kasus ini telah menderita demam selama 3-14 hari dengan temperatur suhu minimal 38,5 derajat Celsius. Penurunan demain pada penderita dengan isolasi kuman positif terjadi setelah 3 hari pada 8 penderita termasuk 2 penderita dengan isolasi S.paratyphi dan dalam waktu 5 hari pada 10 penderita lainnya. Pada 12 penderita dengan kemaknaan serologik untuk demam tifoid penurunan demam terjadi dalam 3 hari pada 6 kasus, tetapi 2 diantaranya masih diterapi sampai hari ke 5. Ke 6 kasus sisanya demam turun dalam 4 - 6 hari, dimana dua diberikan terapi selama 3 hari sedangkan sisa lainnya diterapi 5 hari dengan fleroxacin. Semua kasus yang sebelumnya positif biakan kuman berubah jadi negatif setelah terapi selesai diberikan. Tidak dijumpai releps maupun pembawa kuman pada seri ini. Dapat disimpulkan bahwa terapi fleroxacin 3 - 5 hari telah dapat mencapai efikasi klinik dan bakteriologik yang sempurna untuk penyakit demam tifoid dan paratifoid yang non-kompiklasi. (Med J Indones 2002; 11: 41-7)
\end{abstract}

\begin{abstract}
The objective of this study was to evaluate clinical and bacterialogical effect of short course fleroxacin in uncomplicated typhoid and paratyphoid fever patients. Four hundred $\mathrm{mg}$ of fleroxacin was given oraly once daily for a period of 3 to 5 days. The diagnosis of typhoid and paratyphoid fever was established by clinical picture as well as blood culture or Widal serology test. Thirty patients in whom the clinical picture was confirmed as a typhoid or paratyphoid infection were eligible for this investigation. They consisted of 15 males and 15 females ranging in age from 18-38 years average 27.5 years of whom 18 were diagnosed by blood culture consisting of 16 S.typhi positive cases and two S.paratyphi A, while 12 other cases were positively confirmed by serial Widal agglutination serology. These cases suffered from fever between 3-14 days with a minimum recorded body temperature elevation of 38.5 degrees Celsius. Clinical response with defervescence of fever was obtained in the positive blood culture group within 3 days (8 patients) including 2 cases positive for S.paratyphi A and within two additional days ( 5 days) in the remaining 10 cases. In the twelve cases with a positive serology for typhoid fever a clinical response was obtained for defervescence within 3 days ( 6 cases) with 4 of these cases were on 3 days of fleroxacin and 2 cases on 5 days of fleroxacin. In the remaining 6 serologic positive cases fever resolved after 4-6 days with an average of 5 days with one on 3 days of fleroxacin and the rest $(5$ cases) on 5 days of fleroxacin. All positive blood culture cases reverted to negative after the fleroxacin course. No relapse or carrier state was recorded in this serie. It may be concluded that a 3 to 5 days closely monitored course of fleroxacin has excellent clinical as well as bacteriological efficacy in noncomplicated typhoid and paratyphoid fever. (Med J Indones 2002; 11: 41-7)
\end{abstract}

Keywords: fluoroquinolones, enteric infections, short course efficacy, open prospective study

The development of fluoroquinolones resulted in a long acting version making it easier for the patients to comply with treatment and also for the nursing

Division of Tropical and Infectious Diseases, Department of Internal Medicine, Faculty of Medicine University of

Indonesia, Jakarta

* Presented at the $12^{\text {th }}$ Mediterranean Congress of Chemotherapy, 11-15 November 2000 in Marrakesh - Marocco profession by utilizing once daily administration for patients in the hospital.' Fleroxacin with a modified structure containing three fluorine atoms attach to the quinolone ring system boosting the gyrase inhibition capacity against most of the Gram-negative bacilli especially Enterobacteriaceae as well as part of the Gram-positive cocci mostly Staphylococcus aureus inclusive of methicillin resistant staphylococci although in very diminished activity. ${ }^{2}$ Besides that it has an 
elimination half life of about 13,6 hours the longest of the existing fluoroquinolones at the moment, excellent bioavailability $(100 \%)$, good tissue penetration and both renal (accounting for $65 \%$ clearance) as well as non renal clearance. ${ }^{3}$

Shorter schedules for treatment of typhoid fever were introduced as early as 1984 with the $3^{\text {rd }}$ generation long acting cephalosporins ${ }^{4.5 .6}$ and were followed thereafter with the $3^{\text {rd }}$ generation fluoroquinolones both in our local environment as well as in the international setting. ${ }^{7,8,9}$

This study was designed to evaluate clinical as well as bacteriological efficacy in typhoid and paratyphoid fever, clinical entities that are very endemic in Indonesia, ${ }^{10}$ by using a single daily oral dose of 400 $\mathrm{mg}$ fleroxacin for a period of 3 to 5 days depending on clinical response to treatment.

\section{METHOD}

Patients with a clinical diagnosis of typhoid fever characterized by typical signs and symptoms were screened for entering this study. The patients at least had to be suffering from fever for a minimum duration of 3 days and a maximum duration of 21 days. Their minimal body temperature on admission should be $38,5^{\circ}$ Celsius or above. Besides fever the patients should have at least two other complaints or clinical signs like typhoid tongue, obstipation or diarrhea, relative bradycardia, nausea, anorexia, abdominal pain, headache or chills. The patient was then screened for inclusion and exclusion criteria. Exclusion criteria consisted of age below 18 years, females that were pregnant or lactating, those patients who already were on antityphoidal antimicrobials or had previous history of hypersensitivity to fluoroquinolones. Patients with a history of convulsive disorders or showed signs of complications like altered consciousness or gastrointestinal bleeding were excluded from this study. Both males and females were admitted into this study. Furthermore only those patients who gave informed consent in writing were eligible for final inclusion. Initial clinical data were gathered before administration of the medication and continued by daily monitoring of the clinical course during drug administration and the possibility of adverse drug reactions. Besides the samples for the bacteriological isolation of microorganisms and sensitivity testing the patients were also examined for haematology, liver and renal function and Widal agglutination serology. Any patient with severe aberration from normal laboratory values will automatically withdrawn from the study. The main indication for the duration of treatment was the defervescence of fever. Hence those patients who were afebrile on the $3^{\text {rd }}$ day or thereafter, the medication was discontinued. Treatment was limited to 5 days and in any case with persisted fever after 7 days after starting the treatment was classified as failure.

Bacteriological samples from the blood were taken again after defervescence. Faecal samples were taken at time of discharge from the hospital and a month later. The patients were instructed to report once weekly for clinical examination for one month after treatment in order to establish possible clinical relapse. The patients Widal serology was taken again on the day of discharge. Clinical evaluation was graded as cure with subsidence of all clinical signs and symptoms, improvement when there was incomplete resolution of signs and symptoms at end of treatment, failure was the condition for lack clinical response during and after treatment was halted. Bacteriological cure was the condition when eradication of offending microorganisms was obtained after end of treatment and was not found again in the original site of infection (blood) or in any other potential niche which in typhoid infection in particular is in the enteric tract (Table 1). The number of patients included in this open study was set at 30 patients. As soon as this number of patients were obtained according to the results of the bacteriological culture which had to be positive for S.typhi or S.paratyphi or by a significant rise of the Widal agglutination test conforming to local specifications the study discontinued new recruitments. This study was performed according to the Good Clinical Practice Guidelines ${ }^{11}$ and approved by the Committee on Health Ethics, Faculty of Medicine, University of Indonesia in Jakarta. Statistical analysis was applied chi-square test for non parametric variables and student $t$ test for parametric variables.

\section{RESULTS}

Forty patients were studied consisting of 21 males and 19 females of whom 30 patients could be confirmed by positive bacteriological culture (18 patients) and serology (12 patients) to suffer from enteric fever. These 30 patients consisted respectively of 15 males and 15 females. Their age range was between 18 and 38 year with an average of 27,5 years. The main clinical complaint was of fever lasting for 3 up to 14 
Table 1. Study flow chart fleroxacin short course for typhoid fever

\begin{tabular}{|c|c|c|c|c|c|c|c|}
\hline & D1 & D2 & D3 & D4 & D5 & Discharge & D28 \\
\hline $\begin{array}{l}\text { Medical history } \\
\text { inclusion/exclusion } \\
\text { procedure }\end{array}$ & $\checkmark$ & - & - & - & - & - & - \\
\hline $\begin{array}{l}\text { Vital signs and clinical } \\
\text { examination }\end{array}$ & $\checkmark$ & $\checkmark$ & $\checkmark$ & $\checkmark$ & $\checkmark$ & $\checkmark$ & $\checkmark$ \\
\hline Bacteriological & $\checkmark$ & - & $\checkmark$ & $\checkmark$ & $\checkmark$ & $\checkmark$ & $\checkmark$ \\
\hline Isolations & Blood & & \multicolumn{3}{|c|}{ According to Rx course (blood) } & Stool & Stool \\
\hline Serology & $\checkmark$ & - & - & - & - & $\checkmark$ & - \\
\hline
\end{tabular}

Clinical cure Improvement Failure

Bacteriological cure Bacteriological failure

\section{Evaluation :}

: Subsidence of all clinical signs \& symtoms (CSS)

: Incomplete resolution CSS at end of treatment

: Lack of clinical response during treatment

: Eradication of micro organisms (M.O.)

: Still presence of M.O. after treatment

Table 2. Duration of fever before \& during treatment with $400 \mathrm{mg}$ fleroxacin

\begin{tabular}{|c|c|c|c|c|}
\hline Fever before treatment & $\mathrm{N}$ & Fever dur & g treatment & \\
\hline 3-5 days & 7 & $\begin{array}{l}1 \text { day }: 1 \\
2 \text { days : } 2 \\
3 \text { days : } 1\end{array}$ & $\begin{array}{l}4 \text { days : } 2 \\
5 \text { days : } 1 \\
6 \text { days :- }\end{array}$ & $\begin{array}{l}\text { Av } \\
3 \text { Days }\end{array}$ \\
\hline 6-9 days & 13 & $\begin{array}{l}1 \text { day : } 2 \\
3 \text { days : } 3\end{array}$ & $\begin{array}{l}5 \text { days : } 8 \\
6 \text { days :- }\end{array}$ & $\begin{array}{l}\text { Av } \\
3,8 \\
\text { Days }\end{array}$ \\
\hline $10-14$ days & 10 & $\begin{array}{l}1 \text { day : }- \\
2 \text { days : } 1\end{array}$ & $\begin{array}{l}4 \text { days : } 2 \\
5 \text { days : } 2\end{array}$ & $\begin{array}{l}\text { Av } \\
3,8 \\
\text { Days }\end{array}$ \\
\hline Range & & 3 days : 4 & 6 days : 1 & \\
\hline 3-14 days & 30 & $\leq 3$ days : 14 & days $(4-6): 16$ & \\
\hline
\end{tabular}

Chi-square test between 3-5 days and 6-9 days $=3,6$

days. The other symptoms consisted of headache $(90 \%)$, obstipation $(70 \%)$, anorexia $(60 \%)$, diarrhea $(40 \%)$, chills $(20 \%)$, relative bradycardia $(20 \%)$, cough (15\%), and clinical signs of liver enlargement $(10 \%)$, splenic enlargement $(5 \%)$ or both $(5 \%)$.

The results of intervention with treatment of $400 \mathrm{~g}$ fleroxacin daily resulted in defervescence as shown in Table 2.
As can be seen from Table 2 defervescence was obtained sooner in the patients with a shorter history of fever, the defervescence occurred slightly earlier than in the patients with a longer history of fever before admittance, giving rise to difference in the remittance of fever.

Accordingly 14 patients in whom the fever resolved within 3 days received a treatment of 3 days $400 \mathrm{mg}$ fleroxacin daily, while the 16 other patient received 
fleroxacin for 5 days. Even the patients in whom defervescence was obtained on the $6^{\text {th }}$ day only got 5 days of fleroxacin treatment showing that the medication still exerts bacteriocidal action even after discontinuation of administration strengthening the belief that a 5 day duration of treatment should be enough for typhoid and paratyphoid fever ( 2 cases in this serie). It may be explained explicitly that this compound has a long half-life persisting in body fluids even after it has been discontinued.

The flow chart of patients included is shown in figure 1. As described above there were 30 patients will typhoid and paratyphoid fever and 10 patients with various other infections. All had a recent history of fever and at first were suspected of suffering from typhoid fever. These 10 patients of various etiologies received respectively 3 days of fleroxacin treatment (8 patients), 4 days (1) and 5 days (1) with an $80 \%$ cure rate. The failures seen in this non-typhoid fever group of patients was a case with staphylococcal bacteraemia that did not resolve and was labelled as failure since fever continued far beyond the duration of treatment and another case was diagnosed as bronchopneumonia. On the other hand 4 cases with enterobacterial infection cleared within 3 days while 4 other cases consisting of bronchopneumonia (1), unspecified fever (2) and febrile diarrhea (1) all resolved within 3 days of treatment. One case with an Escherichia coli urinary sepsis with E.coli isolated both from the blood and urine received 4 days of fleroxacin treatment with instant relief.
There was not one case of relapse occurring in this study. The faecal culture of probable development of a S.typhi carrier situation showed that none of the thirty cases had S.typhi or S.paratyphi in their stool one month after the end of treatment. Two cases had enteric pathogens in their faeces, one with a multi resistant strain of E.coli while the other had a Salmonella spp. not related to the initial isolation. None of the cases showed signs of clinical relapse during the weekly follow up for one month. So it could be concluded that clinical as well as bacteriological efficacy was $100 \%$ in this serie (Table 3 ).

Table 3. Clinical and bacteriological efficacy short course fleroxacin $\operatorname{Rx}(\mathrm{N}=30)$



* Unrelated to initial typhoid fever infection

* MDR = Multiple Drug Resistant

Adverse reaction noted in this serie that consisted of symptoms that were not present at time of admission included gastric upset in two patients $(5 \%)$ and insomnia in another patient $(2,5 \%)$. These adverse

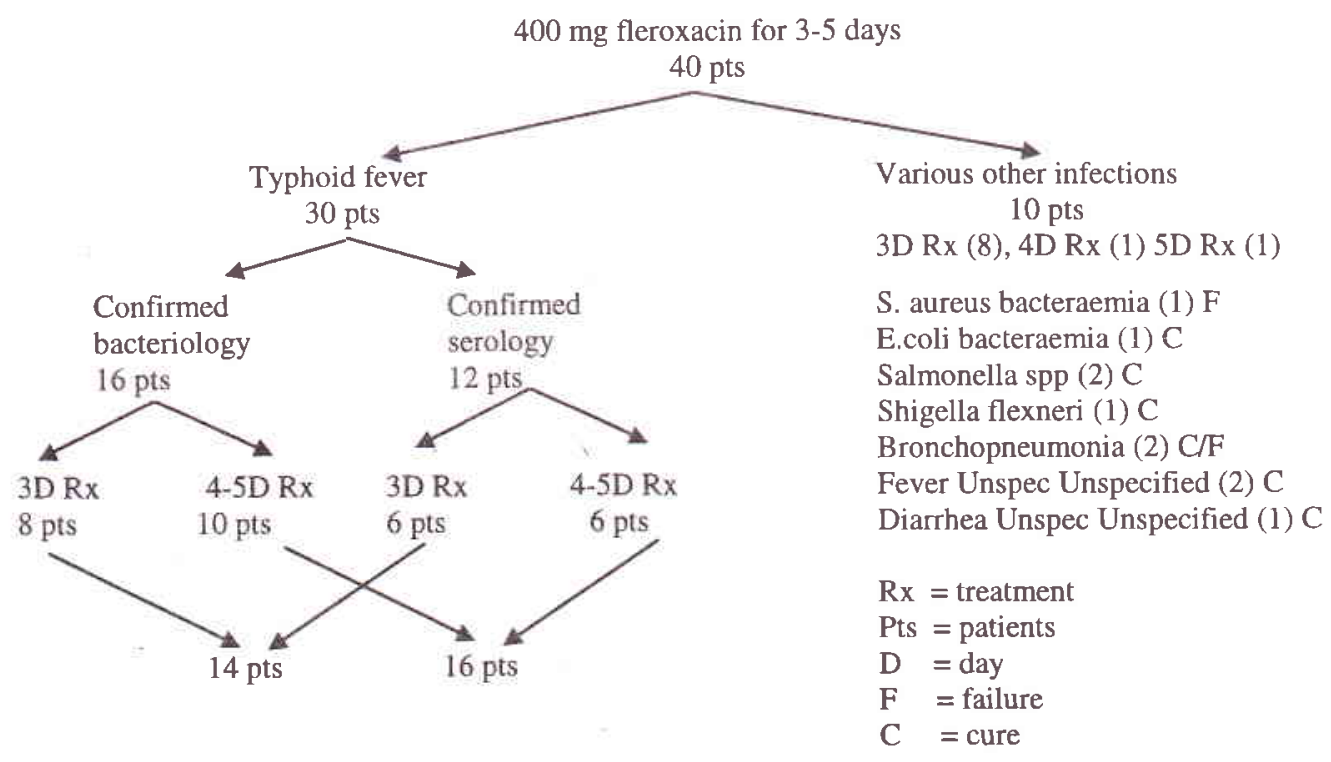

Figure 1. Patients flow chart 
reactions completely disappeared after treatment ended. In both patients due to very good clinical response to treatment duration of therapy only lasted 3 days. Gastric upset occurred not long after administration of the first tablet in both patients. These patients were later known to have been suffering from dyspepsia in their past histories of previous illnesses. The patient with insomnia was noted after two administration of $400 \mathrm{mg}$ fleroxacin and was probably related to very late administration of fleroxacin during a weekend period and could be related to unproper timing of administration that should be executed during early morning period to avoid this problem.

\section{DISCUSSION}

Fleroxacin had previously been used for treatment of typhoid using once daily $400 \mathrm{mg}$ for 7 days in a world wide setting on 4 continents mostly in developing countries with results that reached bacteriological efficacy in $96 \%$ in a total of 28 patients and clinical efficacy of $83 \%$ for the 7 day course ${ }^{12}$ However another study in the South East Asia region carried out by Hien et. al. reported $100 \%$ clinical and. bacteriological cure in 16 patients with a single dose of $400 \mathrm{mg}$ fleroxacin with a treatment duration of 7 days. $^{13}$

A shorter duration of treatment for 5 days was reported by Duong et.al. ${ }^{14}$ In 41 patients he obtained a $97,5 \%$ clinical and $100 \%$ bacteriological cure. A multi center local study around the same time with ciprofloxacin short course 3 days 2 x $500 \mathrm{mg}$ resulted in a clinical success rate of $84,9 \% .{ }^{15}$ With higher concentration for fleroxacin in the gall bladder up to 2 to 4 times than ciprofloxacin ${ }^{16}$ it may explain the better results in the study carried out also by Duong where 22 patients obtained both an $100 \%$ clinical as well as bacteriological efficacy (see table 4).

Besides fleroxacin relative short course with excellent results including non-appearance of carrier states were obtained by using pefloxacin $400 \mathrm{mg}$ once daily for 1 week $^{17,18}$ and also by using ofloxacin $600 \mathrm{mg}$ single dose for one week that gave equivalent excellent results without a single appearance of relapse or carrier state. $^{19}$

Compared to the pilot study done in 1997 with a 3 day course of fleroxacin ${ }^{20}$ this study extension resulted as shown above in both a $100 \%$ clinical efficacy for patients with typhoid and paratyphoid fever as well as a $100 \%$ bacteriological efficacy with no positive culture both directly after treatment or on follow - up. One interesting feature of the present study is the immediate response to treatment especially in the patients with very recent onset of fever. From table 2 it can be noted that 4 out of the 7 patients (about $60 \%$ ) with a history of 3-5 days fever experienced defervescence within the $3^{\text {rd }}$ day compared to 5 out of the $13(40 \%)$ patients with a history of 6-9 days fever and 5 and of the $10(50 \%)$ with a history of $10-14$ days of fever. A near significance was obtained at $\mathrm{p}=$ 0,05 for a statistical comparison between these values (chi-square 3,6 ), definitely pointing out to us that in case of suspicion for typhoid fever the patient should immediately be treated to obtain better and sooner response and it seems to be the most effective method to warrant early recovery and discharge.

This study also confirmed again that the treatment

Table 4. Various studies of treatment with single dose $400 \mathrm{mg}$ fleroxacin (FLX) / day compared to ciprofloxacin (CIP), pefloxacin (PEF) and ofloxacin (OFL)

\begin{tabular}{|c|c|c|c|c|c|c|}
\hline $\begin{array}{c}\text { Reference } \\
\text { number }\end{array}$ & $\begin{array}{c}\text { Year of } \\
\text { report }\end{array}$ & $\begin{array}{l}\text { Medication } \\
\text { used }\end{array}$ & $\begin{array}{l}\text { Duration of } \\
\text { treatment }\end{array}$ & $\begin{array}{c}\text { Number of } \\
\text { cases }\end{array}$ & $\begin{array}{l}\text { Clinical } \\
\text { efficacy }\end{array}$ & $\begin{array}{c}\text { Bacteriological } \\
\text { efficacy }\end{array}$ \\
\hline Arnold ${ }^{12}$ & 1993 & FLX & 14 days & 35 & $100 \%$ & $96 \%$ \\
\hline Nelwan ${ }^{18}$ & 1993 & PEF & 7 days & 20 & $100 \%$ & $100 \%$ \\
\hline $\operatorname{Hien}^{13}$ & 1994 & FLX & 7 days & 16 & $100 \%$ & $100 \%$ \\
\hline Nelwan ${ }^{19}$ & 1994 & OFL & 7 days & 12 & $100 \%$ & $100 \%$ \\
\hline Nelwan $^{15}$ & 1995 & CIP & 6 days & 31 & $100 \%$ & $100 \%$ \\
\hline Duong $^{14}$ & 1995 & FLX & 5 days & 41 & $97,5 \%$ & $94 \%$ \\
\hline Duong $^{14}$ & 1995 & FLX & 3 days & 22 & $100 \%$ & $100 \%$ \\
\hline Nelwan $^{20}$ & 1997 & FLX & 3 days & 4 & $100 \%$ & $100 \%$ \\
\hline
\end{tabular}


with fluoroquinolones on an average attain an afebrile condition after 3,5 days. Various studies have shown the same for ciprofloxacin 3,6 days, ${ }^{21}$ ofloxacin 3,1 days $^{22}$ and pefloxacin 2,9 days. $^{23}$

The follow-up studies in this serie for typhoid and paratyphoid fever patients did not record a single case of relapse and also no fecal carrier state was found one month later. The same condition as noted in our earlier follow up studies that cases could harbor asymtomatic Salmonella spp. in their faeces was also true for this study.

Previous studies in Jakarta showed always the same trend in about 5-10\% of patients with follow up for a possible typhoidal carrier state that the more often we do the post treatment fecal sampling the more often we will be able detect Salmonella spp. in the stools.

With regards to the adverse reactions in this study, it was completely in line with reports on clinical use of fluoroquinolones. Ball and Tillotson reported that the gastrointestinal tract and central nervous system are the main sites for side effects encountered with the majority of fluoroquinolones. ${ }^{24} \mathrm{As}$ it turned out in this study that it was no exception with two cases of gastric upset and another case of insomnia after start of treatment but both were completely reversible and were probably causes by the medication used in this study respective reported to be 11 and $9 \%$ by Ball compared to respective 5 and $2,5 \%$ in this study.

Another interesting aspect of this study occurred in the 10 cases who were of totally different etiology in whom 8 out of the 10 could be treated efficiently. Eight were given a 3 days course of $400 \mathrm{mg}$ fleroxacin daily and one had a 4 day course, the cases that failed with fleroxacin treatment was a case with stapylococcal bacteraemia who after one week still suffered from fever with fleroxacin being discontinued on the $5^{\text {th }}$ day according to protocol and another case of bronchopneumonia in whom treatment was switched to I.V. betalactam treatment. In this context it should always to be kept in mind that there is diminished sensitivity to methicillin-resistant staphylococci. ${ }^{25}$ However on the other hand it was very noteworthy that with a short course of fleroxacin 2 septic condition could be overcome respectively an urinary sepsis caused by Escherichia coli and another was a Shigella flexneri infection that lately showed multiple drug resistance tendencies in our clinical setting. Salmonellosis (2) febrile diarrhea (1) and fever of unknown origin (2) could all be treated successfully with fleroxacin, for community acquired pneumonia it was partly successful.

It may be concluded that a short course of $400 \mathrm{mg}$ fleroxacin daily for 3-5 days is effective to cure patients with typhoid and paratyphoid fever and that the decision to administer for 3 or 5 days will depend completely on the individual response to treatment . In this study almost half (14 out of 30 patients) could be treated successfully with only 3 days of fleroxacin making it a most attractive cost-effective treatment schedule for typhoid and paratyphoid fever. It also turned out that this short course seemed to be effective in various other febrile community acquired infection in our clinical setting.

\section{Acknowledgement}

The author/investigator hereby acknowledge the full support received from PT. Roche Indonesia for carrying out this study. The medical and paramedical staff of the Department of Internal Medicine Persahabatan Hospital are thanked for their full cooperation and also the Department of Microbiology Persahabatan Hospital in particular Dr. Julianti Gunawan for their effort in proper execution of the bacteriological studies. Full devotion to clinical follow up of patients by Dr. Budi Setiawan of the Division of Tropical and Infectious Disease Department of Internal Medicine Faculty of Medicine University of Indonesia is hereby fully acknowledge and appreciated.

\section{REFERENCES}

1. Cullmann W, Geddes AM, Weidekamm E, Urwyler H, Braunsteiner A. Fleroxacin : a review of its chemistry, microbiology, toxicology, clinical efficacy and safety. Int. J Antimicrob Agents 1992; 2 : 203-30.

2. Paganoni R, Herzog C, Braunsteiner A, Hohl P. Fleroxacin in-vitro activity world-wide against 20.807 clinical isolates and comparison to ciprofloxacin and norfloxacin. J Antimicrob Chemoth 1988; 22 (Suppl. D) : 19-23.

3. Stuck AE, Kim DK, Frey FJ. Fleroxacin Clinical Pharmacokinetics. Clin Pharmaco Kinet 1992; 22 (2) 116 21.

4. Stoeckel K. Pharmacokinetics of Rocephin, a highly active new cephalosporin with an exceptionally long biological half-life. Chemotherapy 1981; 27 (SuppI. 11) : 42-6.

5. Lassere R, Ranoa C, Sangalan RP, Santiago L. Three day treatment of typhoid fever in adults: Randomized comparative study of ceftriaxone in comparison with a 14 
day course of chloramphenicol. Proc. $14^{\text {th }}$ ICC Kyoto Japan, Univ of Tokyo Press 1985 : 1996-7.

6. Nelwan RHH, Hendarwanto, Zulkarnain I, Soemarsono $H$ : A Preliminary report on the use of ceftriaxone in typhoid fever. Digestive Disease and Sciences 1986; 31 (10) Abstracts World Congress Gastroenterology page 29S.

7. Carbon $C$, Weber $P$, Lery $M$, Bouissougant $Y$, Cerf $M$. Shortterm ciprofloxacin therapy for typhoid fever. J Infect Dis $1987 ; 155: 833$.

8. Nelwan RHH, Zulkarnain I, Hendarwanto, Widodo D, Pohan HT and Soemarsono H : Short course treatment with ciprofloxacin in typhoid fever. Suppl JAMA Southeast Asia , $1992 ; 8$ (Oct) : 59-62.

9. Limson BM. Short course chemotherapy of typhoid fever. Proc. $4^{\text {th }}$ Western Pacific Congress on Chemotherapy and Infectious Diseases Manila 1994 ; 338-41.

10. Arjoso S, Simanjuntak CH. Typhoid fever and Salmonellosis in Indonesia. Med J Indon 1998; 7 (suppl 1):20-3.

11. Hutchinson D. ICH Harmonized tripartite guidelines for good clinical practice/Declaration of Helsinki. The Trial Investigator's GCP Handbook. Brookwood Medical Publications 1997; 34-47.

12. Arnold K, Hong CS, Nelwan R, Zavalo-Trujillo I, Kadio A, De Oliverira Barros MA, de Garis S. Randomized comparative study of fleroxacin and chloramphenicol in typhoid fever. Am J Med 1993; 94 (Suppl. 3A) : 195 S $200 \mathrm{~S}$.

13. Hien TT, Duong NM, Ha HD, Hoa NTT, Diep TS, Phi LT, Arnold K. A randomized, comparative study of fleroxacin and ceftriaxone in enteric fever. Trans Roy Soc Trop Med Hyg 1994; $88: 464-5$.

14. Duong NM, Vinh Chau NV, Van Anh DC. Hoa NTT, Hoai Tam DT, Ho VA et al. Short course treatment of typhoid fever JAMA - Southeast Asia 1995: $11: 21$ - 5 .

15. Nelwan RHH, Hendarwanto, Zulkarnain I, Gunawan J, Supardiman H, Yusuf H, Soedjana P, Syahroni A. A comparative study of short course ciprofloxacin treatment in typhoid fever. Drugs 1995, 49 (Suppl. 2) 462 - 5.
16. Frantzides CT, Edmiston CE, Walker AP. Concentration of oral quinolones in human gall bladder, bile and serum in patients undergoing effective cholecystectomy. Proc. $2^{\text {nd }}$ International Congress Prevention of Infection. Nice, France 1992. (Abstract)

17. Nelwan RHH. A preliminary report : Open clinical study of once daily oral pefloxacin (400mg) in typhoid fever. Proc. $5^{\text {th }}$ European Congress of Clinical Microbiology and Infectious Diseases in Oslo, Norway 1991; 190.

18. Nelwan RHH, Widjanarko A, Hendarwanto, Zulkarnain I, Gunawan J. Double blind randomized controlled study of once daily $400 \mathrm{mg}$ pefloxacin short course in typhoid and paratyphoid fever. Med J Univ Indon 1993; 2 : 94-7.

19. Nelwan RHH, Widjanarko A, Hendarwanto, Zulkarnain I, Gunawan J : Studi komparatif terkontrol menggunakan ofloksasin pada demam tifoid, Proc. Peranan Ofloksasin dalam berbagai penyakit infeksi. UPF PD FK UNPAD / RSHS, 5 February 1994 : 1-10.

20. Nelwan RHH : Pengobatan jangka pendek demam tifoid dengan dosis tunggal fleroksasin $400 \mathrm{mg}$ sehari. Addendum KONAS III PETRI, Balikpapan 1997 (5 pp).

21. Ramirez CA, Bran JL, Mejra CR., Garcia JF. Clinical efficacy of of ciprofloxacin in typhoid fever. Proc. $1^{\text {st }}$ International Ciprofloxacin Workshop Leverkusen, Germany 1985:365-9.

22. Wang F, Gu XJ, Zhang MF and Tai TY. 'Treatment of typhoid fever with ofloxacin. Rev Inf Dis 1989 ; 11 (Suppl. 5) : 176.

23. Christiano P, Morelli G, Briante V, Iovene MR, Simioli T, Altucc P. Clinical experience with pefloxacin in the therapy of typhoid fever. Infection $1989 ; 17: 86-7$.

24. Ball P, Tilllotson G. Tolerability of fluoroquinolone antibiotics. Drug Safety $1995 ; 13: 343-58$.

25. Bannerman TL, Wadiak DL, Kloos WE. Susceptibility of Staphylococcus species to fleroxacin. Proc. $3^{\text {rd }}$ Intemational Symposium on new Quinolones. Vancouver 1990; Quinodis : 3 . 